\title{
Identification of the antimicrobial substances produced by Solanum palinacanthum (Solanaceae)
}

\author{
ALINE C. PEREIRA ${ }^{1}$, DENILSON F. OLIVEIRA ${ }^{1}$, GERALDO H. SILVA ${ }^{2}$, \\ HENRIQUE C.P. FIGUEIREDO ${ }^{3}$, ALBERTO J. CAVALHEIRO ${ }^{2}$, DOUGLAS A. CARVALHO ${ }^{4}$, \\ LUCIANA P. SOUZA ${ }^{1}$ and SÁRA M. CHALFOUN ${ }^{5}$ \\ ${ }^{1}$ Departamento de Química, Universidade Federal de Lavras, Caixa Postal 3037, 37200-000 Lavras, MG, Brasil \\ ${ }^{2}$ Departamento de Química Orgânica, Instituto de Química, Universidade Estadual Paulista "Júlio de Mesquita Filho" \\ R. Francisco Degni s/n, 14800-900 Araraquara, SP, Brasil \\ ${ }^{3}$ Departamento de Medicina Veterinária, Universidade Federal de Lavras, Caixa Postal 3037, 37200-000 Lavras, MG, Brasil \\ ${ }^{4}$ Departamento de Biologia, Universidade Federal de Lavras, Caixa Postal 3037, 37200-000 Lavras, MG, Brasil \\ ${ }^{5}$ Centro Tecnológico do Sul de Minas, Empresa de Pesquisa Agropecuária de Minas Gerais \\ Caixa Postal 176, 37200-000 Lavras, MG, Brasil \\ Manuscript received on September 9, 2007; accepted for publication on April 14, 2008; \\ presented by FERNANDO GALEMBECK
}

\begin{abstract}
To find out natural antimicrobial agents as alternative in therapeutics and to preserve food, the methanol extract of Solanum palinacanthum aerial parts was submitted to purification steps guided by antibacterial and antifungal assays. As a consequence, the flavonoid rutin and 3,5-dicaffeoylquinic acid were isolated by column chromatography and high performance liquid chromatography, and identified by mass and nuclear magnetic resonance spectrometry. Minimal inhibitory concentrations (MIC) of the quinic acid derivative against Aeromonas hydrophila, Bacillus subtilis, Staphylococcus aureus and the fungus Aspergillus ochraceus were 250, 1000, 1000 and $>568 \mu \mathrm{g} / \mathrm{mL}$, respectively. Against the same microorganisms, MIC for rutin were $1000,>1000,>1000$ and $35 \mu \mathrm{g} / \mathrm{mL}$, respectively. Rutin was very promising for A. ochraceus control, since its MIC against such fungus was close to the one observed for benzalkonium chloride, which is used as a fungicide in Brazil.
\end{abstract}

Key words: Solanum palinacanthum, 3,5-dicaffeoylquinic acid, rutin, antimicrobial activity.

\section{INTRODUCTION}

Food-borne diseases correspond to a world problem that can be caused by microorganisms or their toxic metabolites. An example is ochratoxin A, a nephrotoxic, hepatotoxic and carcinogenic substance produced by some fungi of the Aspergillus genus that have been found in stored food such as coffee beans. It is also possible to mention enterotoxins produced by Staphylococcus aureus, which cause headache, diarrhea and vomit (Jay 2000). As a consequence, the use of additives to protect food against microorganisms is of great interest to

Correspondence to: Denilson F. Oliveira

E-mail: denilson@ufla.br the food industry. However, consumers are increasingly avoiding products prepared with preservatives of chemical origin due to their undesirable effects on human health. A promising alternative to achieve quality improvement in food commodities and a high degree of safety with respect to pathogenic microorganisms resides on the use of natural products (Rauha 2000). As plants have been important sources of new antimicrobial agents (Rios and Recio 2005), a preliminary evaluation of local plant extracts to identify those with antibacterial and antifungal properties was carried out. One of the best results was observed for the aerial parts of Solanum palinacanthum Dunal (Solanaceae), which presented ac- 
tivity against Aeromonas hydrophila, Bacillus subtilis, Staphylococcus aureus and Aspergillus ochraceus.

$S$. palinacanthum is a perennial herb or subshrub which spreads by means of slender, horizontal rhizomes. It is common in pastures, roadsides and similarly disturbed areas in Brazil (Coleman and Coleman 1982), where it has been used to treat skin diseases (Alves et al. 2006). Although its in vitro antimicrobial activity has already been briefly described in the literature by another research group (Alves et al. 2006), to the best of the authors' knowledge no work has ever been done to identify the antimicrobial metabolites produced by S. palinacanthum. Thus, the methanolic extract of such plant leaves was submitted to purification steps guided by antimicrobial assays in order to isolate and identify those substances.

\section{MATERIALS AND METHODS}

\section{General Experimental Procedures}

All reagents used were of recognized analytical grade. Acetic acid and methanol were HPLC-grade. During purification steps, solvent concentrations were carried out in a rotary evaporator at $35^{\circ} \mathrm{C}$ followed by $24 \mathrm{~h}$ in a freeze-drier. Except when mentioned otherwise, all fractions were submitted to antibacterial diffusion assays and antifungal assays to direct fractionation. Column chromatography (CC) was carried out on silica gel 60 (230-400 mesh, Merck) or Amberlite XAD-16 (Sigma). Mass spectrometry (MS) analyses were performed on an Agilent 1100 LC/MS Trap equipped with an electrospray interface. Samples $(1.0 \mathrm{mg})$ were dissolved in water:methanol $(1: 1,1.0 \mathrm{~mL})$ and $20 \mu \mathrm{L}$ were directly injected into the interface. Deuterated dimethyl sulphoxide (DMSO-d6) was used as solvent for nuclear magnetic resonance (NMR) analyses, performed on a Varian instrument $\left({ }^{1} \mathrm{H}\right.$ NMR: $500 \mathrm{MHz}$ and $\left.{ }^{13} \mathrm{C} \mathrm{NMR:} 125 \mathrm{MHz}\right)$ using solvent peak as reference. Two dimensional NMR techniques (COSY, HMQC, HMBC and NOESY) were performed using standard Varian programs.

\section{EXTRACTION AND ISOLATION PROCEDURE}

Fresh leaves of Solanum palinacanthum Dunal (Solanaceae), collected in Lavras city, Minas Gerais State (Brazil), and identified at Herbarium ESAL (ESAL 06644), at Universidade Federal de Lavras, were sub- mitted to exhaustive methanol extraction at room temperature. Part of the crude extract was submitted to the antibacterial $(10 \mathrm{mg} / \mathrm{mL})$ and antifungal $(4 \mathrm{mg} / \mathrm{mL})$ assays. Then, $10 \mathrm{~g}$ of the $S$. palinacanthum crude extract were extracted exhaustively with hexane, ethyl acetate and methanol. A $3.5 \mathrm{~g}$ aliquot of the fraction soluble in methanol was submitted to $\mathrm{CC}$ on silica gel. As eluents were used methanol, water and $0.1 \% \mathrm{HCl}$. Part of the active material eluted with methanol (400 mg) was submitted to $\mathrm{CC}$ on Amberlite, using water and methanol as mobile phases. Part of the fraction eluted through the resin with methanol (176 $\mathrm{mg}$ ) was purified on a HPLC system (Varian equipped with a 9050 UV detector at $254 \mathrm{~nm}, 9012$ ternary pump and 9300 automated injector) using a Phenomenex Gemini silica C18 column $(5 \mu \mathrm{m}, 250 \times 10 \mathrm{~mm})$. Gradient of water:methanol (80:20 to $32: 68$ in $16 \mathrm{~min}, 32: 68$ to $0: 100$ during $10 \mathrm{~min}$ ) at $4.5 \mathrm{~mL} / \mathrm{min}$ was used to elute substances, yielding seven fractions. Fraction six (F6, $27 \mathrm{mg}$, eluted between 14.5$15.0 \mathrm{~min}$ ) and fraction seven (F7, $68.2 \mathrm{mg}$, eluted between 15.0-25.0 $\mathrm{min}$ ) presented antimicrobial activity. F6 (20 mg) was purified on the same HPLC column using a $0.1 \%$ acetic acid:methanol (50:50) solution at $4.5 \mathrm{~mL} / \mathrm{min}$ as mobile phase, which resulted in only one active fraction (rutin, $5.0 \mathrm{mg}$, elution at 8.0-8.6 $\mathrm{min}$ ). For the purification of F7 (20 mg), a $0.1 \%$ acetic acid: methanol $(45: 55)$ solution at $4.5 \mathrm{~mL} / \mathrm{min}$ was used as mobile phase, resulting in one active fraction (3,5-dicaffeoylquinic acid, 7.4 mg, 7.7-8.5 min). NMR and MS analysis were employed to identify both substances.

\section{ANTIBACTERIAL ASSAYS}

Antibacterial activity was evaluated in duplicates, with four standard bacterial strains acquired from the American Type of Culture Collection (ATCC, USA): Aeromonas hydrophila ATCC 7966, Bacillus subtilis ATCC 6633, Pseudomonas aeruginosa ATCC 27853 and Staphylococcus aureus ATCC 25923. Bacteria were grown in tryptic soy agar (TSA, Acumedia, USA), during $24 \mathrm{~h}$ at $37^{\circ} \mathrm{C}$. From each culture, a cell suspension was prepared with an aqueous $0.85 \% \mathrm{NaCl}$ solution and adjusted to $0.5 \mathrm{MacFarland}$ turbidity. In the next step, a swab was used to inoculate bacteria on the surface of Müeller-Hinton agar (Merck, Germany) plates $(95 \times 15 \mathrm{~mm})$. Subsequently, $40 \mu \mathrm{L}$ from each sample 
(dissolved in ethanol/water 7:3) were deposited in $6 \mathrm{~mm}$ diameter holes made on the agar medium. All plates were incubated at $37^{\circ} \mathrm{C}$ for $24 \mathrm{~h}$. After this period, those fractions affording inhibition zones around the holes were considered active. Chloramphenicol (Sigma, USA) and etanol/water (7:3) were employed as positive and negative controls, respectively.

To determine minimal inhibitory and minimal bactericidal concentrations (MIC and MBC), a broth microdilution assay was employed, using Müeller-Hinton broth (MHB, Biolife, Italy) supplemented with calcium and magnesium cations (Alderman and Smith 2001) and standard bacterial inoculums $\left(7.5 \times 10^{4} \mathrm{CFU} /\right.$ well $)$. The crude extract was dissolved in an aqueous $1 \%(\mathrm{~g} / \mathrm{mL})$ Tween 80 solution $(10 \mathrm{mg} / \mathrm{mL})$ and filtered through a $0.22 \mu \mathrm{m}$ membrane (GV Durapore PVDF, Milipore, USA). Ten twofold serial dilutions were prepared to final concentrations ranging from 5,000 to $9.7 \mu \mathrm{g} / \mathrm{mL}$. The isolated substances were dissolved in DMSO $(2.0 \mathrm{mg} /$ $100 \mu \mathrm{L}$ ) and diluted in MHB, resulting in a $2.0 \mathrm{mg} / \mathrm{mL}$ solution. Twofold serial dilutions were prepared to final concentrations ranging from 1,000 to $1.95 \mu \mathrm{g} / \mathrm{mL}$. Chloramphenicol (Sigma, USA) and DMSO were used as positive and negative controls, respectively. After $24 \mathrm{~h}$ at $37^{\circ} \mathrm{C}$, the experiment was evaluated and $10 \mu \mathrm{L}$ were withdrawn from the content of each well with no visible bacterial growth and subcultured in TSA. MIC was defined as the lowest concentration of the tested substance that prevented a visible bacterial growth and $\mathrm{MBC}$ was defined as the lowest concentration yielding no subcultures during $24 \mathrm{~h}$ at $37^{\circ} \mathrm{C}$.

\section{Antifungal ASSAYS}

To direct fractionation steps, antifungal activity was evaluated with Aspergillus ochraceus isolated from coffee beans as described in the literature (Kulwant et al. 1991). Suspension A was made from such fungus' spores $\left(40 \mu \mathrm{L}-3.69 \times 10^{5}\right.$ spores $)$ and $200 \mu \mathrm{L}$ of an aqueous $1 \%(\mathrm{~g} / \mathrm{mL})$ Tween 80 solution containing the sample to be evaluated at approximately $4.0 \mathrm{mg} / \mathrm{mL}$. Czapek yeast extract agar (CYA) (Kulwant et al. 1991) was sterilized at $120^{\circ} \mathrm{C}$ during $15 \mathrm{~min}$ and deposited $(200 \mu \mathrm{L})$ into each well of a polypropylene 96 wells plate. After CYA solidification, suspension A $(20 \mu \mathrm{L})$ was poured into the wells and the plate was kept at $25^{\circ} \mathrm{C}$, with a $12 \mathrm{~h}$ photoperiod, during $48 \mathrm{~h}$. Assays were carried out with three repetitions, employing benzalkonium chloride and DMSO as positive and negative controls, respectively. Those samples which did not allow fungal growth were considered active.

Minimal inhibitory concentrations were obtained by a broth microdilution assay, using Czapek yeast extract without agar (CYB) and standard fungal inoculums $\left(1 \times 10^{4}\right.$ spores $)$. The crude extract and the isolated substances were dissolved in DMSO $(96.0 \mathrm{mg} / \mathrm{mL}$ and $12.5 \mathrm{mg} / \mathrm{mL}$, respectively) and diluted with CYB (16 mg/mL and $1.14 \mathrm{mg} / \mathrm{mL}$, respectively). Ten twofold serial dilutions were prepared to final concentrations ranging from $8,012.0$ to $15.6 \mu \mathrm{g} / \mathrm{mL}$ (crude extract) and 568.0 to $1.1 \mu \mathrm{g} / \mathrm{mL}$ (isolated substances). After $48 \mathrm{~h}$ at $25^{\circ} \mathrm{C}$, with a $12 \mathrm{~h}$ photoperiod, MIC was the lowest concentration of the tested substance that prevented fungal growth.

\section{RESULTS AND DISCUSSION}

Up to now only a very brief report on the S. palinacanthum antimicrobial activity has been published (Alves et al. 2006). According to the authors, such plant extract could inhibit in vitro the growth of Staphylococcus aureus and Candida albicans. Some studies were also found in the literature on the antibacterial properties of other species of the Solanum genus. For example, $S$. torvum showed activity against Bacillus subtilis, B. cereus, Pseudomonas aeruginosa and $S$. aureus (Wiart et al. 2004), while $S$. nigrum was active against Salmonella typhi (Rani and Khullar 2004). S. trilobatum was able to reduce bacterial load in an aquaculture system (Citarasu et al. 2003) and $S$. incanum could inhibit the growth of B. subtilis, B. cereus, B. pumilus, Enterobacter aerogenes, E. cloacae, Micrococcus kristinae and $S$. aureus (Kambizi and Afolayan 2001). Similarly, in this study it was observed that $S$. palinacanthum prevented the growth of $A$. aeruginosa, B. subtilis, $S$. aureus and the fungus $A$. ochraceus, but $P$. aeruginosa, a resistant bacterium to several antimicrobial agents, was not affected by the methanol extract of that plant (Table I).

The fractionation of such extract guided by antimicrobial assays yielded two substances. One of them, isolated as a pale yellow residue, presented NMR spectra in perfect agreement with data previously reported 
TABLE I

Inhibition zone diameter (IZD), minimal inhibitory concentration (MIC) and minimal bactericidal concentration (MBC) for the crude methanol extract of Solanum palinacanthum aerial part.

\begin{tabular}{l|c|c|c}
\hline \multicolumn{1}{c|}{ Microorganism } & IZD $(\mathrm{mm})$ & MIC $(\mu \mathrm{g} / \mathrm{mL})$ & $\mathrm{MBC}(\mu \mathrm{g} / \mathrm{mL})$ \\
\hline Aeromonas hydrophila & 12.5 & 1250 & 1250 \\
\hline Bacillus subtilis & 9.5 & 5000 & $>5000$ \\
\hline Pseudomonas aeruginosa & $-{ }^{\mathrm{a}}$ & $-{ }^{\mathrm{a}}$ & $-{ }^{\mathrm{a}}$ \\
\hline Staphylococcus aureus & 9.5 & 2500 & 2500 \\
\hline Aspergillus ochraceus & $-{ }^{\mathrm{b}}$ & 8012 & $-{ }^{\mathrm{b}}$ \\
\hline
\end{tabular}

${ }^{a}$ no inhibition. ${ }^{b}$ not performed.

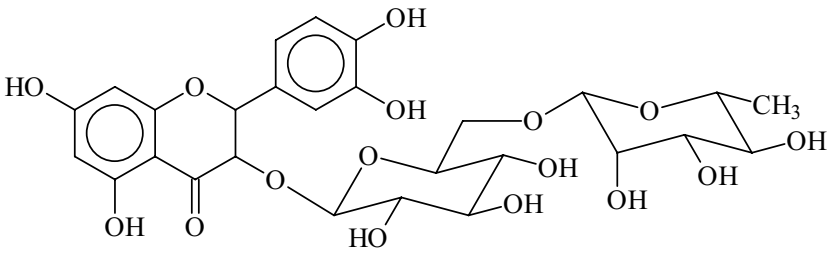

Rutin<smiles>O=C1CC2CC(OC(=O)/C=C/c3ccc(O)c(O)c3)CC(O)(C(=O)O)CC2C1</smiles>

3,5-dicaffeoylquinic acid

Fig. 1 - Antimicrobial substances isolated from Solanum palinacanthum.

for quercetin 3-O- $\alpha$-L-rhamnopyranosyl-(1-6)- $\beta$-D-glucopyranoside (rutin, Fig. 1) (Lee et al. 2004, Niassy et al. 2004, Dubber et al. 2005). The identification of rutin was corroborated by MS analysis, since in the negative mode two peaks at $m / z 609[\mathrm{M}-\mathrm{H}]^{-}$and $645[\mathrm{M}+\mathrm{Cl}]^{-}$ could be observed. In the positive mode a peak at $\mathrm{m} / \mathrm{z}$ $633[\mathrm{M}+\mathrm{Na}]^{+}$was detected.

Rutin, a flavonoid widely distributed in the plant kingdom, presents several biological activities. It has already been isolated from some species of the Solanum genus, like S. tuberosum (Lewis et al. 1998), S. lyratum (Yang et al. 2002) and S. lycopersicum (Van der Rest et al. 2006). However, to the best of author's knowledge, this is the first report on the isolation of such substance from $S$. palinacanthum. When submitted to broth microdilution assays (Table II), it presented low antibacterial activity. Nevertheless, MIC value against $A$. ochraceus was close to the one observed for benzalkonium chloride, the only fungicide used in Brazil to control such fungus in coffee beans (Ministério da Agri- cultura, Pecuária e Abastecimento. Sistema de Agrotóxicos Fitossanitários 2006). Although the antimicrobial properties of rutin have already been described (Cushnie and Lamb 2005, Van der Watt and Pretorius 2001), its potential to control A. ochraceus, a food-borne pathogen in stored food, especially coffee beans, has not been previously reported.

The second active substance was isolated as a light yellow residue whose NMR spectra were in perfect agreement with data (Carnat et al. 2000, Beninger et al. 2004, Clifford et al. 2005) registered in the literature for 3,5-dicaffeoylquinic acid (Fig. 1). In the positive mode, MS spectra presented peaks at $m / z 555[\mathrm{M}+\mathrm{K}]^{+}, 539$ $[\mathrm{M}+\mathrm{Na}]^{+}$and $517[\mathrm{M}+\mathrm{H}]^{+}$, while in the negative mode a peak at $m / z 515[\mathrm{M}-\mathrm{H}]^{-}$was observed. Although caffeoylquinic acid derivatives are known as coffee components, they are widespread in plants (Guerrero et al. 2001), including those of the Solanum genus. Concerning 3,5-dicaffeoylquinic acid specifically, it has been isolated from S. melongena (Whitaker and Stommel 2003), 
TABLE II

Minimal inhibitory concentration (MIC) and minimal bactericidal concentration (MBC) of rutin and 3,5-dicaffeoylquinic acid.

\begin{tabular}{l|c|c|c|c|c|c|c}
\hline \multirow{2}{*}{ Substance } & \multicolumn{2}{|c|}{$\begin{array}{c}\text { Aeromonas } \\
\text { hydrophila }\end{array}$} & \multicolumn{2}{c|}{$\begin{array}{c}\text { Bacillus } \\
\text { subtilis }\end{array}$} & $\begin{array}{c}\text { Staphylococcus } \\
\text { aureus }\end{array}$ & $\begin{array}{c}\text { Aspergillus } \\
\text { ochraceus }\end{array}$ \\
\cline { 2 - 8 } & $\mathrm{MIC}^{\mathrm{a}}$ & $\mathrm{MBC}^{\mathrm{a}}$ & $\mathrm{MIC}^{\mathrm{a}}$ & $\mathrm{MBC}^{\mathrm{a}}$ & $\mathrm{MIC}^{\mathrm{a}}$ & $\mathrm{MBC}^{\mathrm{a}}$ & $\mathrm{MIC}^{\mathrm{a}}$ \\
\hline Rutin & 1000 & $>1000$ & $>1000$ & $-{ }^{\mathrm{b}}$ & $>1000$ & $-{ }^{\mathrm{b}}$ & 35 \\
\hline 3,5-dicaffeoylquinic acid & 250 & 250 & 1000 & $>1000$ & 1000 & 1000 & $>568$ \\
\hline Chloramphenicol & 20 & 50 & 100 & 100 & 200 & $>200$ & $-{ }^{\mathrm{b}}$ \\
\hline Benzalkonium chloride & $-{ }^{\mathrm{b}}$ & $-{ }^{\mathrm{b}}$ & $-{ }^{\mathrm{b}}$ & $-{ }^{\mathrm{b}}$ & $-{ }^{\mathrm{b}}$ & $-{ }^{\mathrm{b}}$ & 8 \\
\hline
\end{tabular}

${ }^{\mathrm{a}}$ Values in $\mu \mathrm{g} / \mathrm{mL} .{ }^{\mathrm{b}}$ not performed.

but the literature reveals no information on the presence of such caffeic acid derivative in S. palinacanthum. Other researchers reported the antibacterial and antifungal activity of this substance (Zhu et al. 2004) as well as its potent antiviral activity ( $\mathrm{Li}$ et al. 2005). Antioxidative (Wang et al. 2003), antiproliferative, tirosinase inhibitory and antihypertensive activity were also attributed to this compound (Iwai et al. 2004, Mishima et al. 2005).

Summarizing, the substances responsible for the antimicrobial properties of the $S$. palinacanthum leaves extract have been isolated and identified as rutin and 3,5dicaffeoylquinic acid. Although their in vitro antibacterial activities were not as pronounced as expected, rutin was very promising to control the fungus $A$. ochraceus.

\section{ACKNOWLEDGMENTS}

This work was supported by Fundação de Amparo à Pesquisa do Estado de Minas Gerais (FAPEMIG), Conselho Nacional de Desenvolvimento Científico e Tecnológico $(\mathrm{CNPq})$ and Coordenação de Aperfeiçoamento de Pessoal de Nível Superior (CAPES).

\section{RESUMO}

Com vistas a descobrir antimicrobianos de origem natural para uso terapêutico ou para a preservação de alimentos, o extrato metanólico das partes aéreas de Solanum palinacanthum foi submetido a fracionamentos direcionados por testes para avaliar a atividade antibacteriana e antifúngica. Em decorrência, o flavonóide rutina e o ácido 3,5-dicafeoilquínico foram isolados por cromatografia em coluna e por cromatografia líquida de alta eficiência, para serem identificados por espectrometria de massas e de ressonância magnética nuclear. As concentrações inibitórias mínimas (CIM) do derivado do ácido cafeico contra Aeromonas hydrophila, Bacillus subtilis, Staphylococcus aureus e o fungo Aspergillus ochraceus foram 250, 1000, 1000 e $>568 \mu \mathrm{g} / \mathrm{mL}$, respectivamente. Contra os mesmos organismos, os valores de CIM para a rutina foram 1000, $>1000$, $>1000$ e $35 \mu \mathrm{g} / \mathrm{mL}$, respectivamente. A rutina mostrou-se muito promissora para o controle de A. ochraceus, pois seu valor de CIM contra tal fungo foi bem próximo ao observado para o cloreto de benzalcônio, que é empregado como fungicida no Brasil.

Palavras-chave: Solanum palinacanthum, ácido 3,5-dicafeoilquínico, rutina, antimicrobiano.

\section{REFERENCES}

Alderman DJ And Smith P. 2001. Development of draft protocols of standard reference methods for antimicrobial agent susceptibility testing of bacteria associated with fish diseases. Aquaculture 196: 211-243.

Alves AA, Pires AF, Linardi VR, Reina LCB AND GALVÃO C. 2006. Atividade Antibacteriana e antifúngica dos extratos brutos etanólicos de Solanum palinacanthum Dunal. III Encontro de Pesquisa das IES-MG, Caratinga, MG, Brasil, 143 p.

Beninger CW, Abou-Zaid MM, Kistner AE, Hallett RH, IQBAL MJ, GRodzinski B AND Hall JC. 2004. A flavanone and two phenolic acids from Chrysanthemum morifolium with phytotoxic and insect growth regulating activity. J Chem Ecol 30: 589-606.

Carnat A, Heitzb A, Fraissea D, CARnat AP And LAMAISONA JL. 2000. Major dicaffeoylquinic acids from Artemisia vulgaris. Fitoterapia 71: 587-589.

Citarasu T, Venkatramalingam K, Babu MM, SEKAR RRJ AND PETERMARIAN M. 2003. Influence 
of the antibacterial herbs, Solanum trilobatum, Andrographis paniculata and Psoralea corylifolia on the survival, growth and bacterial load of Penaeus monodon post larvae. Aquaculture Int 11: 583-595.

Clifford MN, Knight S And Kuhnert N. 2005. Discriminating between the six isomers of dicaffeoylquinic acid by LC-MS. J Agric Food Chem 53: 3821-3832.

Coleman JR and Coleman MA. 1982. Reproductive Biology of an Andromonoecious Solanum (S. palinacanthum Dunal). Biotropica 14: 69-75.

Cushnie TP AND LAMB AJ. 2005. Antimicrobial activity of flavonoids. Int J Antimicrob Agents 26: 343-356.

Dubber MJ, Sewram V, Mshicileli N, Shephard GS AND KANFER I. 2005. The simultaneous determination of selected flavonol glycosides and aglycones in Ginkgo biloba oral dosage forms by high-performance liquid chromatography-electrospray ionization-mass spectrometry. J Pharm Biomed Anal 37: 723-731.

Guerrero G, Suarez M and Moreno G. 2001. Chlorogenic acids as a potential criterion in coffee genotype selections. J Agric Food Chem 49: 2454-2458.

IWAi K, Kishimoto N, Kakino Y, Mochida K AND FUJITA T. 2004. In vitro antioxidative effects and tyrosinase inhibitory activities of seven hydroxycinnamoyl derivatives in green coffee beans. J Agric Food Chem 52: 4893-4898.

JAY JM. 2000. Modern Food Microbiology. Gaithersburg: Aspen Publishers, $720 \mathrm{p}$.

KAmbizi L AND AfOlayAn AJ. 2001. An ethnobotanical study of plants used for the treatment of sexually transmitted diseases (njovhera) in Guruve District, Zimbabwe. J Ethnopharmacol 77: 5-9.

Kulwant S, Jens CF, Ulf T and Mathur SB. 1991. An illustrated manual on identification of some seed-borne Aspergilli, Fusaria, Penicillia and their mycotoxins. Lyngby: Danish Governmant, 123 p.

LEE JH, Ku CH, Sung-Hoon KNB, PARK HW AND KIM DK. 2004. Phytochemical constituents from Diodia teres. Arch Pharmacol Res 27: 40-43.

LEWIS CE, WALKer JRL, LANCASTER JE AND SUtTON KH. 1998. Determination of anthocyanins, flavonoids and phenolic acids in potatoes. Colored cultivars of Solanum tuberosum L. J Sci Food Agric 77: 45-57.

LI Y, But PPH AND OOI VEC. 2005. Antiviral activity and mode of action of caffeoylquinic acids from Schefera heptaphylla (L.) Frodin. Antiviral Res 68: 1-9.

Ministério da Agricultura, Pecuária e Abasteci-
MENTO. 2006. Sistema de Agrotóxicos Fitossanitários. Available at: <http://extranet.agricultura.gov.br/ agrofit_cons/principal_agrofit_cons $>$. Accessed in September $26^{\text {th }} 2006$.

Mishima S, Yoshida C, Akino S And Sakamoto T. 2005. Antihypertensive effects of brazilian propolis: Identification of caffeoylquinic acids as constituents involved in the hypotension in spontaneously hypertensive rats. Biol Pharm Bull 28: 1909-1914.

Niassy B, Um BH, Lobstein A, Weniger B, Koné M And Anton R. 2004. Flavonoïdes de Tephrosia deflexa et Tephrosia albifoliolis. C R Chim 7: 993-996.

RANi P AND KhUllar N. 2004. Antimicrobial evaluation of some medicinal plants for their anti-enteric potential against multi-drug resistant Salmonella typhi. Phytother Res 18: 670-673.

RAUHA JP. 2000. Antimicrobial effects of finnish plant extracts containing flavonoids and other phenolic compounds. Int J Food Microbiol 56: 3-12.

Rios JL AND RECIO MC. 2005. Medicinal plants and antimicrobial activity. J Ethnopharmacol 100: 80-84.

VAN Der Rest B, DANoun S, Boudet AM AND RoCHANGE SF. 2006. Down-regulation of cinnamoyl-CoA reductase in tomato (Solanum lycopersicum L.) induces dramatic changes in soluble phenolic pools. J Exp Bot 57: 1399-1411.

VAN Der Watt E ANd Pretorius JC. 2001. Purification and identification of active antibacterial components in Carpobrotus edulis L. J Ethnopharmacol 76: 87-91.

WANG SY, CHANG HN, LIN KT, Lo CP, YANG NS AND SHYUR LF. 2003. Antioxidant properties and phytochemical characteristics of extracts from Lactuca indica. J Agric Food Chem 51: 1506-1512.

Whitaker WD AND Stommel JR. 2003. Distribution of hydroxycinnamic acid conjugates in fruit of commercial eggplant (Solanum melongena L.) cultivars. J Agric Food Chem 51: 3448-3454.

Wiart C, Mogana S, Khalifah S, MaHan M, ISMail S, Buckle M, Narayana AK and Sulaiman M. 2004. Antimicrobial screening of plants used for traditional medicine in the state of Perak, Peninsular Malaysia. Fitoterapia 75: 68-73.

YANG J, Guo G, Zhou L AND Ding Y. 2002. Studies on chemical constituents of Solanum lyratum. Zhongguo Zhongyao Zazhi 27: 42-43.

ZHU X, ZHANG H AND Lo R. 2004. Phenolic compounds from the leaf extract of artichoke (Cynara scolymus L.) and their antimicrobial activities. J Agric Food Chem 52: 7272-7278. 